\title{
Celtic Studies in Poland: Recent Themes And Developments ${ }^{1}$
}

\author{
Piotr StalmaszczyK
}

\section{Introduction}

Any discussion of Celtic Studies should start with a clear delimitation of the field and scope of research pertaining to Celtology. For the purpose of the bibliography of Celtic Studies in Poland (cf. Stalmaszczyk 2004), I have assumed the following tentative definition:

Celtic Studies are concerned with the languages, literature, culture, mythology, religion, art, history, and archaeology of historical and contemporary Celtic countries and traces of Celtic influences elsewhere. The historical Celtic countries include ancient Gaul, Galatia, Celtiberia, Britain and Ireland, whereas the modern Celtic territories are limited to Ireland, Scotland, Wales, Isle of Man, Cornwall and Brittany. It has to be stressed that Celtic Studies are not identical with Irish (or Scottish, Welsh, or Breton) Studies, though they are, for obvious reasons, closely connected.

Though the definition is not without problems, ${ }^{2}$ it clearly demonstrates that the field of Celtic Studies (CS) is subdivided among a number of different academic disciplines. In this presentation I limit my attention to recent Polish research on Celtic languages and literatures, with only sporadic reference to more general publications. ${ }^{3}$ First, though, it is necessary to mention some of the most important earlier achievements.

Though work devoted to various aspects of Celtic philology and history appeared in Poland already at the turn of the twentieth century, ${ }^{4}$ it is Stefan

\footnotetext{
1 I am very grateful to Prof. Séamus Mac Mathúna for his kind invitation to take part in the first colloquium of the Societas Celto-Slavica, and to Dr. Maxim Fomin for splendid organisational work and assistance.

2 For some recent contributions to the debate on 'Celticity' and Celtic Studies, see Schmidt (1992), Evans (1997), the contributions in Hale \& Payton (2000), and Tristram (2004).

3 There are two reasons for this limitation: firstly, identifying CS on the basis of languages is most fundamental (and secure), cf. Tristram (2004). Secondly, and more personally, I am far better acquainted with research on Celtic languages and literatures than with other subdisciplines of CS. Unfortunately, there is - as yet - no overview of research within other fields of CS in Poland. For a list (admittedly incomplete) of Polish publications on Celtic 'culture and history', see Part Three of Stalmaszczyk (2004).

4 Cf. Rozwadowski (1897), devoted, in considerable part, to Old Irish etymologies and historical phonology; Parczewski (1902), on the Irish mission and the beginnings of Christianity in Poland, and Bieńkowski (1908), on Gaulish representation in Hellenic art.
} 
Czarnowski who deserves to be called the forerunner of CS in Poland. Stefan Czarnowski (1879-1937), the author of numerous studies on sociology, religion, history and theory of culture, also published several articles devoted to Celtic issues, especially literature and religion, and translations of specimens of Celtic literatures (for an overview, see Rosen-Przeworska 1961 and Sadowska 1988). His most important achievement in the field of Celtology was Le culte des héros et ses conditions sociales. Saint-Patrick, Héros national de l'Irlande (Paris 1919), an historical and sociological study of St. Patrick and mediaeval Ireland. In this study, Czarnowski followed closely the methodological assumptions worked out by the French sociologist Émile Durkheim. Le culte des héros et ses conditions sociales is concerned with the social background of hero worship in Ireland. Czarnowski studied the historical reality in the light of documents and the mythical history of Patrick as recorded in the current legends. Though published more than eighty years ago, this study has lost very little of its value and importance, and still deserves to be closely analysed. As observed by Sadowska (1988: 185):

[Czarnowski] was the first in Poland, and one of the first few in Europe, to have shown the scale of relationships between two apparently quite different cultures: Celtic heathenism and Christianity, by demonstrating the penetration of the consolidating Christian tradition by ancient elements which were becoming accommodated in it.

Unfortunately, today Le culte des héros et ses conditions sociales is not known well enough and as a result references to it are extremely rare.

Czarnowski also devoted some shorter studies and conference reports to religion and cult in ancient Gaul (cf. Czarnowski 1925a, 1925b, 1929, 1930a), he also wrote popular essays on Celtic literatures (cf. Czarnowski 1914, 1930b), discussed in section 3, below.

\section{Polish research on Celtic languages}

First linguistic remarks on Celtic languages may be found in the already mentioned grammatical and etymological investigations by Jan Michał Rozwadowski (1897). This was followed by historical and onomastic remarks by Michał Rudnicki (1936) and Tadeusz Milewski (1961). Tadeusz Lehr-Spławiński (1956a, 1956b) was the first to discuss Celtic-Slavonic language contacts, this was followed by Jerzy Kuryłowicz (1961a), and, from an anthropological perspective, by Jan Czekanowski (1961). A recent 
addition to this debate is proposed in etymological investigations of the Celto-Slavonic language connections by Piotr Stalmaszczyk and Krzysztof Tomasz Witczak (1995).

Within the domain of broadly understood 'traditional' and descriptive linguistics the names of Jerzy Kuryłowicz, Leszek Bednarczuk and Witold Stefański have to be mentioned. Jerzy Kuryłowicz (professor at Lvov University, later Wrocław University, and Jagiellonian University) devoted to Celtic languages a number of papers on diverse historical and comparative problems, among them a study of Slavonic, Gothic and Old Irish conjugations (Kuryłowicz 1960), notes on Ogam (Kuryłowicz 1961c), notes on morphological palatalisation in Old Irish (Kuryłowicz 1971), a study of morphological gemination in Celtic and Germanic (Kuryłowicz 1972), and others. Leszek Bednarczuk (Cracow) has produced several studies on Celtic phonology (Bednarczuk 1976, 1977), on typological issues (Bednarczuk 1987, 1989, 1997), and on the Italo-Celtic hypothesis (Bednarczuk 1988b). He has also published a comprehensive chapter on Celtic languages (Bednarczuk 1988a), the most detailed study of the subject available in Polish. Witold Stefański's (Toruń, formerly Poznań) work is concerned with different aspects of Old Irish grammar (Stefański 1988, 1989, 1997) and interrogative and negative structures in Modern Breton (Stefański 2002).

Today, several scholars and institutions conduct research in Celtic linguistics. The most important institution is undoubtedly the Chair of Celtic Philology at the Catholic University of Lublin (KUL), founded in $1991 .^{5}$ The Chair is the only place in Poland where courses in modern Irish and Welsh are offered on a regular basis, and where rigorous research in the field of Celtic linguistics is being conducted. Aidan Doyle (now University College Cork) and Edmund Gussmann (now Poznań) prepared a handbook of Modern Irish in Polish, with detailed grammatical notes and commentaries, phonetic transcriptions, and a short Irish-Polish glossary (cf. Doyle \& Gussmann 1991, 2nd ed. 1997). The same authors compiled a reverse dictionary of Modern Irish (Doyle \& Gussmann 1996), an indispensable (and unique) tool for linguists interested in Irish morphology and word-formation, and more recently Doyle published a descriptive grammar of Modern Irish (Doyle 2001a).

The founder of the Chair, and the first Head (till 1998), was Professor Edmund Gussmann. Since 2004 the Chair has been headed by Eugeniusz Cyran. 
Scholars from KUL have authored several major publications, revised doctoral dissertations and post-doctoral dissertations (i.e. habilitationsschriften), devoted to the phonology, word-formation and syntax of Modern Irish: Anna Bloch-Rozmej (1998), a study of selected phonological processes in Connemara Irish; Anna Bondaruk (2004), a generative analysis of control phenomena in English, Irish and Polish; Eugeniusz Cyran (1997), a study of selected phonological processes in Munster Irish; Aidan Doyle (1992) on noun derivation in Modern Irish, and Doyle (2002), a generative approach to covert and overt pronominals in Irish. ${ }^{6}$ Other unpublished doctoral dissertations devoted to Celtic linguistics include the following: Anita Buczek-Zawiła (1998) on Modern Welsh phonology, Krzysztof Jaskuła (2004) on the phonology of Old Irish, and Maria Bloch-Trojnar (2004) on verbal nouns in Modern Irish.

Scholars from Lublin have often provided new insights on well-known and described problems and processes, e.g. on lenition in Irish (cf. Gussmann 1983, 1986; Bloch-Rozmej 1995, 1998), or mutation in Modern Welsh (cf. Buczek 1995). The new insights were possible due to applying modern theoretical frameworks, such as Government Phonology (cf. Bloch-Rozmej 1995, 1998; Cyran 1995a, 1995b, 1996, 1997), or Minimalism in generative syntactic research (cf. Bondaruk 2004; Doyle 1996, 1998, 2002).

Whereas research carried out in Lublin is very much theory-oriented, scholars from other universities opt for theoretically-neutral research and studies which take into consideration sociolinguistic and historical aspects. For example, Andrzej Skrzypiec (Wrocław) has discussed several Welsh grammatical constructions (cf. Skrzypiec 1991a, 1991b, 2000a), he has also devoted attention to problems of Celtic identity and language change in Wales (cf. Skrzypiec 1998, 1999, 2000b). Sociolinguistic issues have been also discussed by Anna Cisło (Wroclaw; cf. Cisło 1997, 2003), and Piotr Stalmaszczyk (Łódź; cf. Stalmaszczyk 1993, 1997, 2005). The issue of language contact and Celtic-English influences, especially at the lexical level, has been tackled by Elżbieta Majewicz (Poznań; cf. Majewicz 1989), and Stalmaszczyk (1998b, 1999, 2002, 2005).

Historical linguistics is always fundamental in developing a multidimensional approach to language studies, and therefore in CS it is

\footnotetext{
${ }^{6}$ Doyle (2002) appeared as the first volume of a new series - Lublin Studies in Celtic Languages.
} 
of utmost importance to devote appropriate attention to Old Irish and Continental Celtic. Polish linguists have contributed to historical and typological Celtic linguistics, cf. Kuryłowicz (1961b) on Celtic sandhi, Zabrocki (1951) and Bednarczuk (1977) on Celtic lenition, and Stefański $(1986,1989)$ on selected problems of Old Irish grammar. Very importantly, this research is continued by younger linguists, e.g. Krzysztof Jaskuła (Lublin), whose work is devoted predominantly to Old Irish phonology (cf. Jaskuła 1997, 1998, 2004), and Krzysztof Tomasz Witczak (Łódź), whose work covers, among other issues, historical and comparative phonology, Indo-European etymology, language contact in ancient Gaul and substratal features in Celtic (cf. Witczak 2000, 2002a, 2002b). He has recently published a comprehensive study of the language and religion of the ancient Lusitanians (cf. Witczak 2005). Witczak and Stalmaszczyk have co-operated on several Celtic and Indo-European etymological studies (cf. Stalmaszczyk \& Witczak 1990, 1991, 1992, 1993, 1995, 2002).

Other minor publications devoted to historical aspects of Celtic and comparative linguistics include the papers by Iwona Milewska (Cracow) on sandhi in Sanskrit and the Celtic languages (cf. Milewska 2000), Przemysław Popławski (Radom) on Indo-European $*_{s}$ in Celtiberian (cf. Popławski 2000), and Stalmaszczyk (1998a) on the position of Cumbric and Pictish.

Further remarks on Celtic languages may be found in the popular introduction by Alfred F. Majewicz and Elżbieta Majewicz (Poznań) (1983), and in the comprehensive study of British civilisation by Wojciech Lipoński (Poznań), first published in 1995 (3rd ed. 2004). Historical and comparative comments on Celtic languages are also included in the publications of Jadwiga Pstrusińska (Cracow), who organised, at the Institute of Oriental Philology at the Jagiellonian University, the 'Celto-Asiatic Seminar', devoted to interdisciplinary comparative research (cf. Pstrusińska 1997, 1999; see also the contributions in Pstrusińska \& Fear 2000).

\section{Polish research on Celtic literature}

The bibliography of CS in Poland in the twentieth century lists publications which appeared between 1897-2000, cf. Stalmaszczyk (2004). 93 of these publications are devoted to Celtic languages and linguistic problems, 26 to Celtic literature, and 85 to culture, history, mythology, religion, archaeology, 
etc. These numbers show that interest in Celtic literature has been considerably smaller than in languages or culture. Nevertheless, some important publications have appeared, especially in more recent years. As with CS in Poland in general, also in the field of literature it is Stefan Czarnowski who was the first to devote scholarly attention to the field. He published a series of popular essays on Old Irish literature, cf. Czarnowski (1914), and a chapter on Celtic literatures for the great encyclopaedia of world literature, cf. Czarnowski (1930b), followed by a selection of Celtic literary texts translated into Polish, Czarnowski (1932). These essays were popular in character, but with erudite bibliographical notes and commentaries, and, as observed by Sadowska (1988: 185):

... they fully testify to Czarnowski's profound knowledge of the texts he discusses. From the comparative point of view the important point is that Czarnowski demonstrated the contribution of Celtic literatures to the European treasure-trove.

For a very long time nobody continued Czarnowski's work and interests. After more than sixty years Alfred and Elżbieta Majewicz (in co-operation with Andrzej Lubach) prepared a new and very detailed overview of Celtic literary heritage for a modern history of European literatures (cf. Majewicz \& Majewicz 1991). This remains the most comprehensive presentation of the subject in Polish. The lengthy (over 120 pages) chapter provides the necessary background introduction, and detailed individual sections on Irish, Scottish Gaelic, Welsh, Cornish and Breton literatures, furnished with notes on Polish translations (if any) and supplementary readings. Additionally, the text is accompanied by numerous illustrations of books and authors.

Most recently, Anna Cisło (Wroclaw) has published a study (a revised doctoral dissertation, in Polish) devoted to Irish identity and the prose of the literary revival (cf. Cisło 2003), and Piotr Stalmaszczyk (Łódź) has published a book on 'Celtic presence', with chapters on Cornish and Scottish Gaelic literature, and a discussion of place-names in Celtic literature (cf. Stalmaszczyk 2005).

A brief presentation of Celtic literatures may be also found in a concise introduction (in Polish) to Celtic culture by Bożena Gierek (1998). Other popular and minor publications worth mentioning, include an essay on Celtic influences upon Yeats by Rafał Węgrzyniak (1997), an article on the poetry of Cathal Ó Searcaigh by Aidan Doyle (2001b), popular, and 
very personal, essays on different aspects of Celtic culture and literature by Adam Królikowski (1999), and short essays on Irish poetry by Ernest Bryll, a poet, translator and former Polish ambassador to Ireland (cf. Bryll 2000; Goraj \& Bryll 1977).

The last publication to be mentioned in this overview is, very appropriately, an online report on Celtic sources on the Internet, compiled by Katarzyna Gmerek from Adam Mickiewicz University Library Information Services (cf. Gmerek 2005).

\section{Conclusion}

In conclusion of this brief and selective overview of CS in Poland it is necessary to mention the problems facing the discipline and prospects for the future. Three main problem areas may be identified: lack of financial support and institutional recognition, no place for CS in university programs (apart from Lublin), and unsatisfactory knowledge of Celtic languages among scholars willing to conduct research in the field of CS. These problems are obviously interconnected, as lack of financial and institutional support results in marginalisation of CS, which in turn hampers genuine research. On the positive side, the Chair of Celtic Philology at Lublin, entering into its fifteenth year of existence, is no longer the only academic institution devoted to Celtic research. The second one is the Department of Celtic Languages and Literature at the School of English, Adam Mickiewicz University (Poznań), established in 2004, and headed by professor Sabine Heinz (formerly Berlin, Vienna and Lublin). There are plans for establishing similar units at Łódź University and possibly elsewhere as well. Hopefully, the future will see more of such initiatives and, crucially, they will meet with understanding, both within the Polish universities, and abroad, as active support from institutions in Ireland, Scotland, Wales and Brittany is instrumental in further development of research in Celtic Studies. Also at the international level, the establishment of academic societies, such as the Societas Celto-Slavica, should facilitate the co-operation of scholars from different countries.

University of Łódź 


\section{BIBLIOGRAPHY}

Bednarczuk, L., 1976, 'Rozwój konsonantyzmu celtyckiego' [The development of Celtic consonants], in: Sprawozdania z posiedzeń komisji naukowych, PAN Kraków, 19, 1, 36-38.

Bednarczuk, L., 1977, 'Sporne problemy lenicji w celtyckim' [Controversial issues in Celtic mutation], in: Kwartalnik Neofilologiczny 24, vol. 2-3, 133-140.

Bednarczuk, L., 1987, 'An attempt at typological characterisation of the Celtic languages', in: Lingua Posnaniensis 28, 7-13.

Bednarczuk, L., 1988a, 'Języki celtyckie' [Celtic languages], in: Języki indoeuropejskie [Indo-European languages], vol. 2, L. Bednarczuk, ed., Warszawa: Państwowe Wydawnictwo Naukowe, 645-731.

Bednarczuk, L., 1988b, 'The Italo-Celtic hypothesis from the IndoEuropean point of view', in: Proceedings of the First North American Congress of Celtic Studies held at Ottawa from 26th-30th March, 1986, G. W. MacLennan, ed., Ottawa: University of Ottawa, 175-189.

Bednarczuk, L., 1989, 'Structural similarities between Brittonic Celtic and West Romance languages', in: Ollodagos, Actes de la Societe Belge d'Études Celtiques, vol. 1:2, 35-59.

Bednarczuk, L., 1997, 'A typological contribution to the disappearance of $p$ in Common Celtic', in: Zeitschrift für celtische Philologie 49/50, 4349.

Bieńkowski, P., 1908, Die Darstellungen der Gallier in der hellenistischen Kunst (Imagines Celtarum I), Vienna: Alfred Hölder.

Bloch-Rozmej, A., 1995, 'Nasal lenition and the theory of phonological government', in: Licensing in Syntax and Phonology (PASE Studies and Monographs 1), E. Gussmann, ed., Lublin: Folium, 165-185.

Bloch-Rozmej, A., 1998, Element Interactions in Phonology: A Study in Connemara Irish, Lublin: Redakcja Wydawnictw KUL.

Bloch-Trojnar, M., 2004, Verbal Nouns in Modern Irish. Categories and Exponents, (unpublished $\mathrm{PhD}$ dissertation), Catholic University of Lublin.

Bondaruk, A., 2004, PRO and Control in English, Irish and Polish - A Minimalist Analysis, Lublin: Wydawnictwo KUL. 
Bryll, E., 2000, 'Poezja staroirlandzka' [Old Irish poetry], in: Czas Kultury 2/3, 56-63.

Buczek, A., 1995, 'Lenition and fortition: Consonant mutation in Welsh', in: Licensing in Syntax and Phonology (PASE Studies and Monographs 1), E. Gussmann, ed., Lublin: Folium, 187-216.

Buczek-Zawila, A., 1998, Principles and Parameters of Modern Welsh Phonology, (unpublished $\mathrm{PhD}$ dissertation), Catholic University of Lublin.

Cisło, A., 1997, 'Etniczność a język w kontekście irlandzkim' [Ethnicity and language in the Irish context], in: Sprawozdania Wrocławskiego Towarzystwa Naukowego, vol. 51, seria A, 28-32.

Cisło, A., 2003, Tożsamość Irlandczyków w prozie odrodzenia literackiego z przetomu XIX i XX wieku [The Irish Identity in the Prose of the Literary Revival of the Late Nineteenth and Early Twentieth Centuries], Wrocław: Wydawnictwo Uniwersytetu Wrocławskiego.

Cyran, E., 1995a, 'Vocalic systems in government phonology', in: Licensing in Syntax and Phonology (PASE Studies and Monographs 1), E. Gussmann, ed., Lublin: Folium, 217-237.

Cyran, E., 1995b, 'Two makes three? Vowel quality in Modern Irish', in: Papers and Studies in Contrastive Linguistics 30, 167-184.

Cyran, E., 1996, 'Licensing properties of nuclei and principle ranking in Irish', in: The Linguistic Review 13:1, 1-31.

Cyran, E., 1997, Resonance Elements in Phonology. A Study in Munster Irish (PASE Studies and Monographs 3), Lublin: Wydawnictwo Folium.

Czarnowski, S., 1914, 'Dawna literatura irlandzka' [Old Irish literature], in: Tygodnik Polski 2, 347-348, 365-366, 380-383. [Reprinted in Czarnowski, 1956, vol. 3, 11-21]

Czarnowski, S., 1919, Le culte des héros et ses conditions sociales. SaintPatrick, Héros national de l'Irlande, Paris: Travaux de l'Année Sociologiques publiés sous la direction de N. E. Durkheim, Libraire Félix Alcan. [Published in Polish as Czarnowski 1956, vol. 4]

Czarnowski, S., 1925a, 'Herkules Galijski' [Heracles of Gaul], in: Przeglad Historyczny vol. V, 238-260. [Reprinted in Czarnowski, 1956, vol. 3, 139-160] 
Czarnowski, S., 1925b, 'L'arbre d'Esus, taureau aux trois grues et le culte de voies fluviales en Gaule', in: Revue Celtique, vol. XLII, nos. 1-2, 1-57. [Polish translation in Czarnowski, 1956, vol. 3, 173-214]

Czarnowski, S., 1929, 'La biens féminins en droit celtique', in: La revue historique de droit français et étranger 1, 649-651. [Polish translation in Czarnowski, 1956, vol. 3, 134-135]

Czarnowski, S., 1930a, 'Le sanglier mythique des Gaulois et des Bretons insulaires', abstract of conference paper in: Actes $d u$ V-e Congres International d'Histoire des Religions a Lund 1929, Lund 1930. [Polish translation in Czarnowski, 1956, vol. 3, 217-218]

Czarnowski, S., 1930b, 'Literatury celtyckie' [Celtic literatures], in: Wielka Literatura Powszechna Ilustrowana, Warszawa: Trzaska, Evert i Michalski, vol. 3, 3-66. [Reprinted in Czarnowski, 1956, vol. 3, 22-96]

Czarnowski, S., 1932, 'Literatury celtyckie' [Celtic literatures], in: Wielka Literatura Powszechna Ilustrowana, Warszawa: Trzaska, Evert i Michalski, vol. 6, 95-118. [Reprinted in Czarnowski, 1956, vol. 3, 97-133]

Czarnowski, S., 1956a, Studia z dziejów kultury celtyckiej. Studia z dziejów religii. Dzieta Tom III [Studies on Celtic culture. Studies on history of religion. Works, vol. 3], Warszawa: Państwowe Wydawnictwo Naukowe.

Czarnowski, S., 1956b, Kult bohaterów i jego społeczne podtoże. Święty Patryk bohater narodowy Irlandii. Dzieła Tom IV [The cult of heroes and its social background. St. Patrick, the national hero of Ireland. Works, vol 4] Warszawa: Państwowe Wydawnictwo Naukowe. [Polish translation, by A. Glinczanka, of Czarnowski 1919]

Czekanowski, J., 1961, 'Celto-słowiańska teoria' [Celtic-Slavonic (anthropological) theory], in: Stownik Starożytności Stowiańskich. Encyklopedyczny zarys kultury Stowian od czasów najdawniejszych, W. Kowalenko, G. Labuda \& T. Lehr-Spławiński, eds., vol. 1, part 2, 221-223.

Doyle, A., 1992, Noun Derivation in Modern Irish. Selected Categories, Rules and Suffixes, Lublin: Redakcja Wydawnictw Katolickiego Uniwersytetu Lubelskiego.

Doyle, A., 1996, 'Compounds and syntactic phrases in Modern Irish', in: Studia Anglica Posnaniensia 30, 83-95. 
Doyle, A., 1998, 'Obligatory and optional movement: the evidence from Irish', in: Projections and Mapping. Studies in Syntax (PASE Studies and Monographs 5), P. Stalmaszczyk, ed., Lublin: Folium, 43-55.

Doyle, A., 2001a, Irish (Languages of the World Series) Munich: Lincom.

Doyle, A., 2001b, 'Writing in a dying language: the poetry of Cathal Ó Searcaigh', in: From the Peripheries to the Centre: Essays in (Anglo-) Irish Literature, J. Burzynska \& D. Stanulewicz, eds., Lublin: Maria Curie-Sklodowska University Press, 131-142.

Doyle, A., 2002, Covert and Overt Pronominals in Irish (Lublin Studies in Celtic Languages 1), Lublin: Wydawnictwo Folium.

Doyle, A., \& Gussmann, E., 1991, An Ghaeilge. Podręcznik do nauki języka irlandzkiego [AHandbook of Modern Irish], Lublin: Redakcja Wydawnictw Katolickiego Uniwersytetu Lubelskiego. [second edition 1997]

Doyle, A., \& Gussmann, E., 1996. A Reverse Dictionary of Modern Irish, Lublin: Wydawnictwo Folium.

Ellis Evans, D., 1997, 'Celticity, Celtic Awareness and Celtic Studies', in: Zeitschrift für celtische Philologie 49/50, 1-27.

Gierek, B., 1998, Celtowie [The Celts], Kraków: Instytut Wydawniczy Znak.

Gmerek, K., 2005, 'Źródła celtyckie w Internecie' [Celtic sources on the Internet], in: $E B I B$ 4/2005 (65), available online at: http://ebib.oss.wroc. pl/2005/65/gmerek.php

Goraj, M., \& Bryll, E., 1977, 'Czy można pisać poezję w umierającym języku?' [Is writing poetry in a dying language possible?], in: Literatura na Świecie 11, 178-191.

Gussmann, E., 1983, 'The (un)natural phonology of Modern Irish initial mutations', in: Kwartalnik Neofilologiczny 30, 245-253.

Gussmann, E., 1986, 'Autosegments, linked matrices, and the Irish lenition', in: Linguistics across Historical and Geographical Boundaries, vol. 2, D. Kastovsky \& A. Szwedek, eds., Berlin: Mouton de Gruyter, 891-907.

Hale, A., \& Payton, P., eds., 2000. New Directions in Celtic Studies, Exeter: University of Exeter Press.

Jaskuła, K., 1997, 'Be a stop or give way: Selected Old Irish compound verbs', in: Lingua Posnaniensis 39, 25-38. 
Jaskuła, K., 1998, 'The prosodic hierarchy at work: lenition of voiceless spirants in Old Irish', in: Structure and Interpretation - Studies in Phonology (PASE Studies and Monographs 4), E. Cyran, ed., Lublin: Folium, 183-194.

Jaskuła, K., 2004, The Phonology of Old Irish as a Reflection of Ancient and Mediaeval Sound Change, (unpublished $\mathrm{PhD}$ dissertation), Catholic University of Lublin.

Królikowski, A., 1999, Epopeja Celtów [The Celtic Epic], Częstochowa: Wydawnictwo WSP.

Kurylowicz, J., 1957, 'Morphological gemination in Keltic and Germanic', in: Studies presented to Joshua Whatmough on his sixtieth birthday, E. Pulgram, ed., 's-Gravenhage: Mouton, 131-141.

Kuryłowicz, J., 1960, 'On certain analogies and differences between the Slavonic, Gothic and Old Irish conjugations', in: Biuletyn Polskiego Towarzystwa Językoznawczego 19, 117-124.

Kuryłowicz, J., 1961a, 'Celtycko-słowiańskie stosunki językowe’ [CelticSlavonic language contacts], in: Stownik Starożytności Stowiańskich. Encyklopedyczny zarys kultury Stowian od czasów najdawniejszych, W. Kowalenko, G. Labuda \& T. Lehr-Spławiński, eds., vol. 1, part 2, 229-230.

Kuryłowicz, J., 1961b, 'Hibernica', in: Biuletyn Polskiego Towarzystwa Językoznawczego 20, 121-136.

Kurylowicz, J., 1961c, 'Note sur l'Ogam', in: Bulletin de la Société de Linguistique de Paris 56, fasc. 1, 1-5.

Kuryłowicz, J., 1967, 'Ein altirisches Lautgesetz', in: Beiträge zur Indogermanistik und Keltologie, Innsbrucker Beiträge zur Kulturwissenschaft XIII, Innsbruck, 213-214.

Kuryłowicz, J., 1969, 'La désirence verbale -r- en indo-europeen et en celtique', in: Études Celtiques 12, 1968-69, fasc. 1, 7-20.

Kurylowicz, J., 1971, 'Morphological palatalisation in Old Irish', Travaux Linguistiques de Prague 4. Études de la phonologie, typologie et de la linguistique générale. Volume dédicé aux professeurs Josef Vachek et Vladimir Skalička, Prague: Academia, 67-73.

Lehr-Spławiński, T., 1956a, 'Kilka uwag o stosunkach językowych celtycko-prasłowiańskich' [Some remarks on Celtic-Proto-Slavonic language contacts], in: Rocznik Slawistyczny 18, 1-10. 
Lehr-Splawiński, T., 1956b, 'Ze stosunków językowych celtyckosłowiańskich' [On Celtic-Slavonic language contacts], in: Zeszyty Naukowe Uniwersytetu Jagiellońskiego, Filologia 2: Prace Językoznawcze, Kraków: Wydawnictwo Uniwersytetu Jagiellońskiego, 256.

Lipoński, W., 1995, Narodziny cywilizacji Wysp Brytyjskich [The birth of civilisation in the British Isles], Poznań: Kantor Wydawniczy SAWW [second edition: Poznań: Bene Nati, 1996], third edition published 2004 as Dzieje kultury brytyjskiej [History of British civilisation], Warszawa: Wydawnictwo Naukowe PWN.

Majewicz, A., \& Majewicz, E., 1983, Języki celtyckie na Wyspach Brytyjskich [Celtic languages in the British Isles], Polska Akademia Nauk, Nauka dla wszystkich 368, Wrocław: Ossolineum.

Majewicz, A., \& Majewicz, E., 1991, 'Literackie dziedzictwo Celtów' [Celtic literary heritage], in: Dzieje literatur europejskich [The history of European literatures], vol. 3 part 2, Warszawa: Państwowe Wydawnictwo Naukowe, 647-768.

Majewicz, E., 1984, 'Celtic influences upon English and English influences upon Celtic languages', in: Lingua Posnaniensis 27, 45-50.

Milewska, I., 2000, 'Sandhi w sanskrycie i w językach celtyckich' [Sandhi in Sanskrit and in Celtic languages], in: Collectanea Celto-Asiatica Cracoviensia, J. Pstrusińska \& A. Fear, eds., Cracow: Księgarnia Akademicka, 61-70 [with a summary in English].

Milewski, T., 1961. 'Die stolzen Namen der Kelten', in: Bibliotheca Classica Orientalis 6, 114-115.

Parczewski, A., 1902, 'Początki chrystianizmu w Polsce i Misja irlandzka' [Beginnings of Christianity in Poland and the Irish Mission], in: Rocznik Towarzystwa Przyjaciót Nauk, Poznań, vol. XXIX, 183-257.

Popławski, P., 2000, 'Indo-European $*_{s}$ in Celtiberian', in: Studia Indogermanica Lodziensia III, 11-20.

Pstrusińska, J., 1997, 'Why the Celto-Asiatic seminar? 1. Celtic versus Indo-Iranian', in: Iranica Cracoviensia. Cracow Iranian Studies in memory of Władystaw Dulęba, Kraków: Cornelius Publishing House, 195-215.

Pstrusińska, J., 1999, Old Celtic Cultures from the Hindukush Perspective, Kraków: Universitas. 
Pstrusińska, J., \& Fear, A., eds., 2000, Collectanea Celto-Asiatica Cracoviensia, Cracow: Księgarnia Akademicka

Rosen-Przeworska, J., 1961, 'Zagadnienia celtyckie w pracach Stefana Czarnowskiego' [Celtic issues in the work of Stefan Czarnowski], in: Archeologia Polski 6:2, 273-312.

Rozwadowski, J.M., 1897, 'Zzagadnień gramatycznychietymologicznych' [Grammatical and etymological investigations], in: Rozprawy Wydziatu Filologicznego Akademii Umiejętności 25, Kraków, 389-427.

Rudnicki, M., 1936, 'Die Slaven, Kelten und Germanen in Bassin des Baltischen Meeres zu Beginn der indoeuropäischen Ära', in: Slavia Occidentalis 15, 131-141.

Sadowska, E., 1988, 'Stefan Czarnowski: a Polish forerunner of Celtic studies', in: Hemispheres 3, 171-194.

Schmidt, K. H., 1992, 'The Celtic problem. Ethnogenesis (location, date?)', in: Zeitschrift für celtische Philologie 45, 38-65.

Skrzypiec, A., 1991a, 'Kilka uwag a walijskich czasownikach modalnych' [Some remarks on Welsh modal verbs], in: Studia Linguistica 13, Acta Universitatis Wratislaviensis 1063, 59-72.

Skrzypiec, A., 1991b, 'Czas gramatyczny w języku walijskim' [Tense in Welsh], in: Studia Linguistica 14, Acta Universitatis Wratislaviensis 1200, 39-58.

Skrzypiec, A., 1998, 'Dekompozycja tożsamości kulturowej na przykładzie Walijczyków' [Decomposition of cultural identity - the Welsh case], in: A. Furdal, ed., Studia nad językami i kulturami europejskimi. PAN, Oddział we Wrocławiu, 67-73.

Skrzypiec, A., 1999, 'Language change due to language contact in a minority language: The Welsh example'. in: Anglica Wratislaviensia XXXV (=Festschrift for Professor Jan Cygan, M. Post, ed.), 89-95.

Skrzypiec, A., 2000a, 'A preliminary study of the Welsh passives and their Polish equivalents', in: Poznań Studies in Contemporary Linguistics 36, 151-157.

Skrzypiec, A., 2000b, 'Celtowie: mit czy rzeczywistość?' [The Celts myth or reality?] in: Nauka Wroctawska: Biuletyn Informacyjny oddziatu PAN we Wroctawiu 9-10, 7-11. 
Stalmaszczyk, P., 1993, 'Scottish Gaelic - Notes on history, causes of decline and chances of survival', in: Sprache-Kommunikation-Informatik (Linguistische Arbeiten 294), J. Darski \& Z. Vetulani, eds., Max Niemeyer Verlag, Tübingen, 705-708.

Stalmaszczyk, P., 1997, 'Celtyckie języki Irlandii, Szkocji i Wyspy Man: Historia i teraźniejszość' [The Celtic languages of Ireland, Scotland and Isle of Man: History and the present], in: Problematyka Brytyjska. Studia interdyscyplinarne, K. Kujawińska-Courtney, R. Machnikowski \& A. Wójcik, eds., Łódź: Ośrodek Badań i Studiów Brytyjskich, Uniwersytet Łódzki, 97-112.

Stalmaszczyk, P., 1998a, 'Stanowisko języka kumbryjskiego i piktyjskiego w podgrupie brytańskiej języków celtyckich' [The position of Cumbric and Pictish within the Brittonic subgroup of the Celtic languages], in: Biuletyn Polskiego Towarzystwa Językoznawczego LIII, 81-93.

Stalmaszczyk, P., 1998b, 'Celtic elements in English vocabulary - a critical reassessment', in: Studia Anglica Posnaniensia 32 (1997), 77-87.

Stalmaszczyk, P., 1999, 'A note on Irish English vocabulary', in: Anglica Wratislaviensia XXXV (= Festschrift for Professor Jan Cygan, M. Post, ed.), 109-113.

Stalmaszczyk, P., 2002, 'Issues in Irish English vocabulary', in: Studia Indogermanica Lodziensia IV, 63-71.

Stalmaszczyk, P., 2004, 'Celtic Studies in Poland in the 20th Century: A Bibliography', in: Zeitschrift für celtische Philologie 54, 170-184.

Stalmaszczyk, P., 2005, Celtic Presence. Studies in Celtic Languages and Literatures: Irish, Scottish Gaelic and Cornish, Łódź: Łódź University Press.

Stalmaszczyk, P., \& Witczak, K. T., 1990, 'Celto-Tocharica I: Three Celtic-Tocharian terms for certain parts of the body', in: Tocharian and Indo-European Studies 4, Reykjavík, 35-44.

Stalmaszczyk, P., \& Witczak, K. T., 1991, 'Celtic *abon- 'river' - a proposal for new etymology’, in: Lingua Posnaniensis 32/33, 205-209.

Stalmaszczyk, P., \& Witczak, K. T., 1992, 'The Celtic word for 'oats, Avena sativa' and its Indo-European equivalents', in: Lingua Posnaniensis 34, 83-87. 
Stalmaszczyk, P., \& Witczak, K. T., 1993, 'Studies in Indo-European vocabulary', Indogermanische Forschungen 98, 24-39.

Stalmaszczyk, P., \& Witczak, K. T., 1995. 'Celto-Slavic language connections: New evidence for Celtic lexical influence upon Proto-Slavic', in: Linguistica Baltica 4, Kuryłowicz Memorial Volume. Part Two, 225-232.

Stalmaszczyk, P., \& Witczak, K. T., 1998, 'Welsh paladr 'spear' and related words', in: Studia Etymologica Cracoviensia Vol. 3, 125-127

Stalmaszczyk, P., \& Witczak, K. T., 2002, 'Etyma Celtica (1-3)', in: Studia Indogermanica Lodziensia IV, 73-79.

Stefański, W., 1988, 'Old Irish deponent and passive', in: Studia Celtica Japonica 1, 13-19.

Stefański, W., 1989, 'Der Konditionalsatz im Altirischen', in: Zeitschrift für celtische Philologie 43, 165-170.

Stefański, W., 1997, 'Die palatalisierung im Irischen und Polnischen: ein kontrastiver Vergleich', in: Zeitschrift für celtische Philologie 49/50, 831836.

Stefański, W., 2002, 'Negative and interrogative structures in Modern Breton', in: Studia Indogermanica Lodziensia IV, 81-86.

Tristram, H., 2004, 'Unwinding the Celtic Englishes in Potsdam: The problem of 'Celticity", paper presented at the fourth colloquium The Celtic Englishes held at the University of Potsdam, 22-26 September, 2004.

Węgrzyniak, R., 1997, 'Yeats: Celtyckie mity i labirynt symboli' [Yeats: Celtic myths and the maze of symbols], in: Dialog 5, 135-141.

Witczak, K. T., 2000, 'Non-apophonic *o in Common Celtic and Latin', in: Studia Indogermanica Lodziensia III, 37-43.

Witczak, K. T., 2002a, 'Remarks on Indo-European substratal features in some Celtic lexical items', in: Studia Indogermanica Lodziensia IV, 87-99.

Witczak, K. T., 2002b, 'The Latin-Gaulish bilingual inscription of Vercelli', in: Studia Indogermanica Lodziensia IV , 101-110.

Witczak, K. T., 2005, Język i religia Luzytanów. Studium historycznoporownawcze [The language and the religion of the ancient Lusitanians. A historical-comparative study], Łódź: Wydawnictwo Uniwersytetu Łódzkiego. 
Zabrocki, L., 1951, Usilnienie i lenicja w językach indoeuropejskich $i w$ ugrofinskim [Fortition and lenition in Indo-European languages and in Finno-Ugric], (especially chapter VII, 171-192: 'Przesuwka w celtyckim' [The mutation in Celtic]), Poznań: Poznańskie Towarzystwo Przyjaciół Nauk.

\section{SUMMARY \\ Piotr StalmaszczyK}

\section{Celtologia polska: WspóŁczesne tendencje}

Choć PIERWSZE NAUKowe uWAGI NA TEM AT JĘZYKóW CELTYCKICH UKAZAEY SiĘ W P IŚM IENNICTWIE P OLSKIM JESZCZE P OD KONIEC XIX w., TO DOP IERO DZIAłALNOŚĆ S STEFANA CZARNOWSKIEGO ZASŁuguJe NA OKREŚLENIE M IANEM 'CELtologiCZneJ', NATOM IAST DALSZY ROZWÓJ TEJ DZIEDZINY NASTĄP IŁW DRUGIEJ P OŁOWIE XX W. ARTYKUŁP RZEDSTAWIA WSPÓłCZESNE OSIĄGNIĘCIA CELTOLOGII POLSKIEJ, KONCENTRUJĄC SIĘ ZWłASZCZA NA BADANIACH DOTYCZĄCYCH JĘZYKÓW I UTERATUR CELTYCKICJ. DO OM ÓWIENIA DOłĄCZONA JEST OBSZERNA BIBUOGRAFIA. 